\title{
A escrita autobiográfica de Tom Malmquist como processo de superação do luto
}

\section{The autobiographical writing of Tom Malmquist as a process of overcoming mourning}

\author{
Camila Gouvea Prates de Paiva ${ }^{1}$
}

DOI: $10.28998 / 2317-9945.2020 n 65 p 71-73$

MALMQUIST, Tom. Em cada momento ainda estamos vivos. Tradução: Carlos Rabelo e Leon Rabelo. São Paulo: Grua, 2019.

\begin{abstract}
Afinal, não só esta, mas todas as autobiografias são sempre imaginárias e reais, se é que podem delimitar fronteiras exatas nesse sentido. Pois se a realidade é de certo modo uma criação imaginária, também a imaginação e a fantasia são realidades contundentes, que revelam integralmente o ser e o mundo concretos em que se apoiaram.
\end{abstract}

(Sérgio Sant'Anna, em As confissões de Ralfo)

O romance Em cada momento ainda estamos vivos, de 2015, foi o processo de escrita de Tom Malmquist sobre seu momento de luto e de superação após a morte de sua companheira Karin Largerlöf e de como a chegada da filha deles em meio a esse turbilhão lhe serviu de forças para continuar.

O livro se inicia com a chegada de Tom e Karin, que está grávida, ao serviço de emergência do hospital, com uma suspeita de pneumonia, mas ao realizar uma série de exames se descobre que ela está com um quadro severo de leucemia. Temos, a partir de então, a narração de todos os desdobramentos da doença de Karin, a necessidade de um parto de emergência e a tentativa extenuante de encontrar uma cura para a mulher, que tem uma morte prematura, sem a oportunidade de conviver com a filha.

A escrita de Tom é sinestésica, a todo o tempo somos levados pela descrição das cores e sensações de se estar dentro de um hospital, que é cinza e frio, além de passagens de extrema objetividade, como ocorre na descrição do momento da morte de Karin:

O enfermeiro parece estar registrando ao computador o que Nygren diz, quando ele de modo quase cerimonial vai em direção às máquinas. A paciente teve parada cardíaca às 5 h52min, o potássio continuou se elevando, ácido láctico estável em vinte e oito, ECMO inalterado com cinco mil e quinhentos ciclos por minutos, 5,1 litros de fluxo, a expectativa de a paciente permanecer com vida é considerada inexistente, e eu decido por desligar o respirador e o EMCO. Faz-se silêncio na sala,

\footnotetext{
${ }^{1}$ Doutoranda e Mestre em Letras pelo Programa de Pós-graduação em Letras da Universidade Estadual de Londrina.
} 
as máquinas param de fazer barulho. Nygren olha o relógio e acrescenta: Hora do óbito, 6h31min (MALMQUIST, 2019, p. 83).

Mesmo retratando a morte da companheira, não há no livro, por parte do narrador, o sentimento de tristeza, apenas uma saudade pelos bons momentos que eles viveram e pela ausência da mulher na vida da filhinha do casal. Isso confere ao romance leveza e cuidado.

O texto é autobiográfico, no entanto, se formos leitores desatentos passaremos grande parte do livro sem saber, pois a informação só está presente na leitura da sinopse na orelha do livro, além de ser possível, em determinados momentos dentro da obra, fazer a correspondência entre o nome da personagem e do autor, entretanto o momento é tão dramático que pode deixar escapar esse detalhe. Como no trecho em que o rapaz descobre que por não ser formalmente casado com Karin terá dificuldades em registrar a bebê Lívia:

[...] Eu quero que o primeiro e o último nome de minha esposa sejam o segundo nome da minha filha, Karin Largerlöf deve constar no nome da minha filha Lívia Karin Largerlöf Malmquist. Sim, é só que "Malmquist" que foi rejeitado, ela diz. [...] Do jeito que está aqui, ela tem o registro de órfã. Mas eu sou o pai dela! Vocês eram formalmente casados? [...] Eu fiz um teste de DNA no Karolinska, eu sou o pai, eu e a Karin moramos juntos por dez anos, desde então sou eu que cuido da Lívia, o que mais vocês querem? (MALMQUIST, 2019, p. 136-137).

O detalhe que envolve o nome da personagem é importante porque a autobiografia é uma "narrativa retrospectiva em prosa que alguém faz de sua própria existência, na qual autor, narrador e personagem possuem a mesma identidade nominal" (LEJEUNE, 2008, p. 33), ou seja, Tom Malmquist apresenta no livro Em cada momento ainda estamos vivos um recorte de sua própria vida, a experiência da doença da companheira de vários anos e o nascimento e os primeiros cuidados da filha recém-nascida.

Mas afinal, o que é a autobiografia e qual a sua real relação com Em cada momento ainda estamos vivos? Uma explicação simplória nos diria que é a narração da vida de alguém, escrita pela própria pessoa, de forma documental ou ficcional. Mas um romance autobiográfico é mais do que isso, porque nele estão implícitas uma série de questões, como coloca Philippe Lejeune (2008):

A promessa de dizer a verdade, a distinção entre verdade e mentira constituem a base de todas as relações sociais. Certamente é impossível atingir a verdade, em particular a verdade de uma vida humana, mas o desejo de alcançá-la define um campo discursivo e atos de conhecimento, um certo tipo de relações humanas que nada têm de ilusório. A autobiografia se inscreve no campo do conhecimento histórico (desejo de saber e compreender) e no campo da ação (promessa de oferecer essa verdade aos outros), tanto quanto no campo da criação artística (LEJEUNE, 2008, p. 104).

Porque escrever de si, deixar no papel algo tão profundo e tão particular? No caso de Malmquist é para processar o processo de luto de forma catártica. Sua felicidade em ganhar uma filha, uma nova vida surgindo, é arrancada ou descompensada a partir da morte da esposa, arrebata por uma leucemia aguda e muito rápida. 
No livro de Tom Malmquist temos autor, narrador e personagem centrados na mesma pessoa, um sujeito real com CPF, pois para que exista a autobiografia é preciso haver uma relação de identidade onomástica entre autor, aquele que "escreveu" a obra, que tem o nome escrito na capa, o narrador e a pessoa de quem esse narrador fala, ou seja, é preciso um narrador em $1^{a}$ pessoa. No livro Em cada momento ainda estamos vivos há essa relação entre pessoa que escreve e pessoa que é narrada.

Philippe Lejeune dá a esse processo o nome de "pacto autobiográfico", pois é a concordância entre os nomes de autor-narrador-personagem que vai firmar com o leitor "a afirmação, no texto, dessa identidade, remetendo, em última instância, ao nome do autor, escrito na capa do livro" (2008, p. 26).

Tom Malmquist é ao mesmo tempo seu narrador e sua personagem, resultando em um romance autobiográfico que explica a vida da maneira como ela é, sem cortes ou floreios, desde a primeira sonda passada em Karin, quando eles chegam ao hospital, até o final com a pequena Lívia no parquinho de areia.

\section{Referências}

LEJEUNE, P. O pacto autobiográfico: de Rousseau à internet. Belo Horizonte: Editora UFMG, 2008.

SANT'ANNA, S. As confissões de Ralfo: uma autobiografia imaginária. Rio de Janeiro: Relume-Dumará, 1995.

VELASCO, T. M. Escritas de si contemporâneas: uma discussão conceitual. In: XIV Congresso Internacional ABRALIC, 2015, Belém - PA. Anais [...]. Belém - PA: ABRALIC, 2015. p. 1-13. 